\title{
LOS CARROS ALEGÓRICOS DEL CARNAVAL DE NEGROS Y BLANCOS
}

\author{
Julio César Goyes-Narváez
}

En el contexto del carnaval popular Andino de Negros y Blancos del departamento de Nariño, al sur de Colombia, los artistas crean y exponen carrozas o carros alegóricos, esculturas monumentales y efímeras que protagonizan el 6 de enero, día de reyes, como parte central del desfile que dura largas horas y que atraviesa las principales calles de ciudades y poblaciones. La multitud en su recorrido "juega" y se divierte en las plazas públicas, en las calles o en los balcones de las residencias, la gente se pinta con cosméticos de diversos colores, especialmente negro, y esparcen sobre los espectadores serpentinas y talcos, al tiempo que bailan y beben licor. Seguido de una breve reseña sobre el origen y estructura de esta singular fiesta, se describen y analizan los textos alegóricos, a la luz de testimonios de artistas populares del carnaval de Pasto y del juego entre sus cuerpos, la materialidad empleada y la imaginación. [abstract on page 278]

\section{CARNAVAL ANDINO, MESTIZAJE, RELATOS DEL TACTO, ALEGORÍAS, OBRAS DEL IMAGINAR.}




\title{
DE LOS SATURNALES AL CARNAVAL DEL SUR DE COLOMBIA
}

\begin{abstract}
Los orígenes de esta fiesta popular Andina son muy antiguos y tan universales como locales. Sus comienzos y posterior desarrollo poseen ataduras de diversos órdenes, configurando un campo interdisciplinario prometedor para las ciencias sociales y humanas. Desde el mito de Saturno, dios de la agricultura asociado a Jano, el dios de la semillas, que reinó en una época en la que los hombres eran iguales y había abundancia, pasando por los saturnales romanos, cuya fiesta comenzaba con un sacrificio y con la li-

bertad de esclavos por el tiempo en que duraban las fiestas, estas eran experimentadas

como un retorno efectivo y completo (aunque provisorio) al país de la edad de oro. Las tradiciones de las saturnales sobrevivieron en el carnaval de la Edad Media, que representó con más plenitud y pureza que otras fiestas de la misma época, la idea de renovación universal (BAJTIN, 1974: 13).
\end{abstract}

1 La 4a reunión del Comité Intergubernamental de la Unesco para la Salvaguarda del Patrimonio Cultural Inmaterial reunido en Abu Dhabi (Emiratos Árabes Unidos), entre el 28 de septiembre $y$ el 2 de octubre del 2009, anunció al mundo su decisión de incluir los Carnavales de Negros y Blancos del departamento de $\mathrm{Na}$ riño en Colombia, como patrimonio de la humanidad, junto con las procesiones de Semana Santa de Popayán, capital del departamento del Cau$\mathrm{ca}$, zona limítrofe con $\mathrm{Na}$ riño. Colombia ya había obtenido este reconocimiento con el Palenque de San Basilio (2006) y el Carnaval de Barranquilla (2008).

\section{Neftali Benavides cuen-} ta que el día para ejercer esa libertad fue el 5 de enero y se denominó "la fiesta de los negritos". Ante los acontecimientos de la independencia criolla de España (1810-1820), esta fiesta de negros desaparece, pero pronto es retomada por Pasto, población vecina de Popayán.
La llegada de los españoles a América fue definitiva para que se transportara el espíritu y forma de las fiestas medievales que, al contacto con la cultura ancestral indígena, tomó características especiales. No obstante, los rituales y fiestas indígenas americanas fueron perseguidas y ocultadas durante la conquista y durante parte de la colonia española, sin embargo lentamente resurgieron hasta constituir los carnavales que hoy se celebran. De igual forma, las luchas de liberación de los esclavos negros en Latinoamérica constituyen otro origen, fácil de adivinar en el carnaval de Negros y Blancos ${ }^{1}$, cuyo recuerdo más cercano es haber logrado en 1807, según cuenta Neftali Benavides, "un día de libertad" ante el Virreinato español de Popayán, en Colombia (BENAVIDES, apud ZARAMA, 1999). ${ }^{2}$

Desde entonces, con desiguales saltos históricos, la celebración de los negritos retornará enmascarada en una clase social que no era la original, pero que lentamente se apropiaba del legado en su jolgorio y esparcimiento, tal como lo describe en su crónica José de Castro en un periódico pastuso de 1887:

Paseábamos distraídos por el atrio de la Catedral (La iglesia Matriz de nuestros antepasados, hoy catedral de San Juan Bautista) el 5 del presente, mirando si sería verdad o talvez mentira todo aquello. De improviso oímos voces animadas y distinguimos luego una numerosa partida de máscaras, disfrazados con bastante decencia y buen gusto y de una manera adecuada al papel que ellos habían escogido. Pues a seguirlos y nos fuimos detrás de la partida (...) Una nube de pollos intrépidos, algunos pintados de negro el 
rostro, verdaderos piratas de corazones. Jóvenes bizarros con todo el ardor de su edad; alegres espirituales, galan-

tes y decididores, y que cual tornasolados colibríes, buscan para picotear las más tiernas y delicadas flores. A fulgure el tempestate, liberanos Dominie! (...) Las máscaras y los negritos bailan y bromean, apuran sendas copas de Champaña, y rebosante de entusiasmo y alegría, salen y van a otra casa, a donde ya se había anunciado con una galante tarjeta para brindar la pinta (BENAVIDES, 1974, p. 9-10).

Este sincretismo cultural estructura el Carnaval de Negros y Blancos, tradición popular genuina que incorpora y rinde homenaje a las etnias indígena, negra y blanca. Por eso la historiadora nariñense Lydia Inés Muñoz Cordero habla de matrices ("madres") culturales, y ubica la matriz precolombina con sus ritualidades agrarias y cósmicas, fundamentalmente en torno a la siembra, maduración y cosecha del maíz para la zona andina; la matriz hispánica que aporta muchos elementos, tales como los instrumentos musicales (la chirimía), el teatro a través de los autos sacramentales, los "cuadros vivos", escenas y pastorelas, que terminarán configurando los "carros alegóricos" o carrozas que hoy conocemos y que constituyen la máxima expresión del arte popular del Carnaval de San Juan de Pasto; la matriz africana, con la incorporación de la etnia negra a la economía de América: sus fiestas, sus cantos complementados con danza, la oralidad, la pantomima, los cantos responsoriales, las cuadrillas, grupos de gentes que animaban con su jolgorio el "juego de negritos", y las nuevas expresiones como forma de resistencia al colonialismo y como adaptación a las nuevas condiciones históricas (CORDERO, 2007: 61-80).

Desde lo cultural el Carnaval desborda aun los referentes históricos, retomando su ritual y ceremonial y adaptándose a las condiciones regionales, "principalmente en su relación con el mestizaje cultural, lo que ha dado origen a nuevas consideraciones y debates sobre su razón de ser y sobre las especificidades de su práctica que lo hacen diferente de otras manifestaciones festivas" (PÉREZ, 2005, p. 21). ${ }^{3}$ Teniendo en cuenta que los antecedentes y manifestaciones carnavalescas y festivas son bastante anteriores, el carnaval de negros y blancos, en su sentido actual, comienza en Pasto en 1927, señalando los días 6 y 7 de enero como fechas de jolgorio popular, siendo el 7 el día principal. El 4 de enero de 1928 arriba "la familia Castañeda", imprimiendo en el carnaval el sentido de mestizaje que porta la cultura campesina. Para el año de 1929, el Carnaval de Pasto se celebra en los días 4, 5, y 6 de enero, cronograma muy 3 Este autor observa que en algunos lugares (Nariño puede ser uno de ellos) el Carnaval crea una tradición y por consiguiente "es acogido como referencia permanente que repercute en las esferas de lo económico y de lo social, logrando que éste no sea una improvisación sino una forma de vida" (PÉREZ, 2005, p. 21). parecido al actual. A partir de 1950 el carnaval se consolida con una dinámica estética, artística y sociocultural propia. Las matrices mestizas y sincréticas cobran todo su sentido Andino (CORDERO, 2007, p. 163-202).

A medida que se desarrolla e inserta dentro de la cultura popular nariñense, el carnaval de Negros y Blancos integra (absorbe) otras fiestas y celebraciones, hasta estructurar un macrotexto de características multiexpresivas e interdisciplinarias que inquieta a 
4 Una aproximación al macrotexto del carnaval desde la performance como campo de estudio interdisciplinar se puede consultar en Goyes-Narváez, 2008.

\section{Se entiende como pun-} to de ignición el sentido de una emoción singular que conmueve, un escozor que tiene lugar en lo que a simple vista no se entiende pero clama nuestra atención. GONZÁLEZ-REQUENA (1999, p. 9-30). "Los ritos y la sociedad del espejo", entrevista a Jesús González Requena" por Julio César Goyes-Narváez. En Ómnibus, $n$. 28, año $V$, septiembre 2009. http:// www.omni-bus.com/n28/ cine.html. más de un investigador social. ${ }^{4}$ Teniendo en cuenta los preparativos que cubren gran parte del año, el carnaval, en la última década, se inicia el 28 de diciembre con el "por inocentes" o carnaval de agua (otrora carnaval de las flores) y la presentación de las reinas populares. Siguen los "años viejos" el 31 de diciembre (desfile de carros alegóricos referidos al fin y comienzo de año), luego el día de la juventud, el 2 de enero, los colegios se toman las calles y el rock la plaza "La Pola" de Ipiales; le sigue "el carnaval de la frontera" (en Ipiales) y de la juventud (en Pasto), el 3 de enero. El carnavalito, la fiesta de los niños, es el 4 de enero. Se acrecienta el entusiasmo el 5 de enero, día de Negros, entrada de las familias Ipial (Ipiales) y Castañeda (Pasto), emblemas colectivos que hacen su entrada en las ciudades acompañadas de comparsas multitudinarias, alegres y coloridas, y llega a su éxtasis el 6 de enero, día de Blancos y desfile mayor de trajes individuales y por parejas, comparsas, murgas, grupos de danzas y carrozas o carros alegóricos.

\section{EL DESFILE DE CARROZAS. EL PUNTO DE IGNICIÓN ${ }^{5}$}

Una pregunta inicial es ¿̇por qué uno de los acontecimientos artísticos populares más elaborados y esperados del Carnaval son los carros alegóricos? Estos hacen su entrada triunfal el 6 de enero, "día de reyes", último día de la fiesta carnestoléndica. Estas carrozas acompañadas de jugadores carnavalescos cierran el largo desfile que dura más de seis horas, antecedido por disfraces, murgas, grupos de danzantes y comparsas. Los carros alegóricos son obras esculturales de gran tamaño, algunas monumentales, que han sido confeccionadas durante un período que va de tres a seis meses y en el cual participan familias enteras, amigos y vecinos. Son obras guiadas con experiencia, ingenio y persistencia por maestros del carnaval, algunos formados en escuelas de bellas artes, pero la mayoría en la escuela del carnaval o escuela de la vida, como ellos mismos afirman.

Se puede hablar de tres fases por las que atraviesa la creación de los carros alegóricos: fase de preproducción, ciclo largo o de preparación que puede durar seis o más meses; fase de producción, celebración, ritualización y performance, período que engloba el ciclo del carnaval propiamente dicho, va del 28 de diciembre al 6 de enero; y fase de posproducción, recepción, transformación y rediseño. El ciclo, de esta manera, se renueva.

Artistas que año tras año perfeccionan su técnica y enriquecen el carnaval a cambio de aplausos y vivas, como dice el Maestro Chicaiza, que lleva casi 50 años participando, y para el que "es una satisfacción más que todo interna, cuando se forma esa idea y el 6 de enero se siente como si expandiera eso, como si flotara, como si fuera el alma que 
flotara en el aire". 6 Para el Maestro Humberto Erazo, experimentado carrocero, los aplausos son la compensación a su esfuerzo, pues uno como artista y como cultor del carnaval se siente orgulloso cuando lo aplauden, es el estímulo más grande que tiene uno, porque, dese cuenta, que una carroza se demora tres a cuatro meses en la elaboración y el trabajo y la exposición al público apenas son de seis horas.

De igual forma el Maestro Roberto Otero, uno de los más jóvenes, formula un acto comunicativo recíproco entre el público y los artistas del carnaval, "los aplausos hacen que uno se esmere e investigue", dice.

La entereza y creatividad se reflejan en estas carrozas hechas con sacrificio, ansiosamente esperadas e intuidas por los espectadores-jugadores, pues el recuerdo del año anterior les hace imaginar (desear) lo que ese día acontece o puede acontecer. La pregunta del inicio vuelve a tener un nuevo sentido aquí: ¿Por qué el suspenso se configura con mayor intensidad en este fragmento (texto) del desfile que, a su vez, es un fragmento del carnaval (macrotexto)? La gente de todas las edades y géneros (jugadores, visitantes, vendedores y curiosos), se ubican desde la noche anterior tomando posesión en la senda por donde pasa el desfile. Amanecen a sus orillas con el propósito de asegurar un lugar privilegiado tan cerca como se pueda - para vivir el carnaval y apreciar sus dones artísticos, pues

los espectadores no asisten al carnaval, sino que lo viven, ya que el carnaval está hecho para todo el pueblo. Durante el carnaval no hay otra vida que la del carnaval. Es imposible escapar, porque el carnaval no tiene ninguna frontera espacial" (BAJTín, 1974, p. 13).
6 Este testimonio y los que se han seleccionado para lo que sigue, hacen parte de entrevistas a artistas del carnaval, de las cuales nueve aparecen en el audiovisual Carros Alegóricos (52 min.), una coproducción de la Universidad Nacional de Colombia (IECO-Quinde), la Universidad del Cauca (Gicea) y el Fondo Mixto de Cultura de Nariño, producido por Javier Tobar y dirigido por Julio César Goyes, 2009. Cabe anotar que los artistas de Carros Alegóricos son numerosos, la mayoría están asociados a Asoarca. Aquí se citan algunos de los que participaron en el carnaval del 2009.

7 Falta estudiar las soterradas tramas entre "el carnaval del perdón", los "carnavales de dios" o el "día de la fiesta del maíz - la alegría" y el carnaval Andino de Negros y Blancos.

Esta es su marca distintiva con respecto a otras fiestas y carnavales, el de Negros y Blancos es auténticamente popular, como observa Michel Vovelle, asociado con la conciencia colectiva que aspira a unificarse, pero que también pone en escena sus conflictos (VOVELLE, 1998). Ahora bien, desde el punto de vista de los sujetos festivos, estos conflictos pueden sanar como un acto de reconciliación, a la manera como se dona en El Carnaval del Perdón entre los kamëntsá, Valle de Sibundoy, Putumayo, región limítrofe con Nariño. Sin el perdón "la fiesta no tendría la alegría que ordenó el mito, es decir, la fiesta no tendría el festejo comunicativo que presupone toda alegría colectiva" (TOBAR y GÓMEZ, 2004, p. 53). ${ }^{7}$

Además de ser una manifestación popular, el carnaval de Negros y Blancos se impone como un acto artístico auténtico que sobresale en la zona Andina y en Colombia, pues no hay carro alegórico que contenga su fuerza expresiva, su intención estética, su 
8 Xavier (2007) hace un análisis temático del texto de Michel Maffesoli, De la Orgía, criticando, por un lado, la renuncia que el autor hace de "lo individual para perderse en lo colectivo, lo otro, como deidad", sin percatarse que hay otro presupuesto, el de "las tradiciones festivas donde la sociabilidad de la comunidad produce una ganancia de reflexividad (individual y comunitaria) y un esfera pública". (p. 202). Por otro lado, Costa critica a Maffesoli su adhesión al Dioniso orgiástico, sin distinguir que el propio Nietzsche insistió en la "particularidad griega de Dioniso, como dios del arte y de la fiesta, que da lugar a un concepto de 'sociabilidad' (inspirado en Simmiel y desarrollado en Xavier, 1999) que puede complementar el de 'socialidad' de Maffesoli y que incluye la dimensión artístico-festiva y trágica de la existencia" (p. 193). aspiración alegórica. Si el carnaval como fiesta pagana es un retorno de Dioniso, tal como lo concibió Nietzsche en el Origen de Tragedia, este Dioniso no se vincula a lo libertino-orgiástico (bárbaro), sino al dios griego del arte y la fiesta, que, como lo ha observado contundentemente Xavier Costa, "expresa la voluntad de poder como arte", pues "Dioniso es sublimación artística en el origen de la tragedia" (XAVIER, 2007, p. 200). ${ }^{8}$

Comparto con Xavier Acosta el hecho de que el Dioniso festivo, artístico, explica para la Fiesta en general - y para el Carnaval de Negros y Blancos de Nariño, en particular -, "el proceso de sublimación comunitaria de impulsos que comporta el ejercicio cotidiano de la sociabilidad festiva, responsable de la construcción periódica del Evento Festivo" (p. 203). De manera que el Carnaval de Negros y Blancos alcanza su apoteosis artística en los Carros Alegóricos; además su interacción festiva, más allá de la ritualidad y la transgresión, rehace lo social comunitario y la identidad continuamente, año tras año, generación tras generación. Como bien lo anota el investigador valenciano, hay una diferencia entre una sociedad que construye identidades para la fiesta y otra que no las tiene.

\section{RELATOS DEL TACTO}

El trabajo con la materia, es decir con los materiales, es lo que distingue en primera instancia a un maestro de otro, un carro alegórico de otro. Si unos utilizan el modelado tradicional en barro, revestido de capas de papel con engrudo, yeso o encolado, otros usan materiales livianos y sintéticos como el icopor o la espuma, de igual forma lo recubren de papel o de yeso; otros, en cambio, alejándose del papel, buscan un acabado que proporcione resistencia a la intemperie, entonces procesan la fibra de vidrio para esculpir figuras de gran tamaño. No faltan los que mezclan todas estas técnicas, dependiendo de la necesidad creativa que los convoca. Las estructuras de "los monigotes" se hacen en madera y/o hierro, con el empleo de poleas y riendas. Utilizan también mecanismos eléctricos que dan movimiento a las figuras alegóricas que montan en sus carros.

Los talleres de los maestros son espacios singulares. La mayoría de ellos familiares y tan amplios como sus carros alegóricos, repletos de materiales y de figuras del pasado que constituyen una especie de cementerio del carnaval. En ese aparente desorden pleno de afecto y humildad, luchan por expresar su interioridad. Como dice el maestro Diego Caicedo al comparar el carnaval con una fruta en donde el 6 de enero se ve sólo la 
cáscara, el terminado -, esos sentimientos que son el "verdadero jugo de este fruto está aquí en los talleres", por eso "aquí se queda el alma de cada uno de nosotros".

\section{EL PRIMER ESCULTOR}

Los Maestros del Carnaval, a medida que construyen con sus manos figuras, bastidores y adornos para las carrozas, traman un relato que respalda su hacer y argumenta su técnica creativa. El Maestro José Ignacio Chicaiza, uno de los más viejos y respetados artesanos vivos del carnaval, relata el origen de su oficio como un don divino, leyendo a su manera el pasaje bíblico:

Yo creo que el primer escultor fue Dios cuando hizo a Adán de barro, él fue el primer escultor y yo creo que esa es la tendencia nuestra a imitarlo tal vez a él, trabajando la arcilla, o aún cuando hoy hay muchos materiales que se pueden trabajar en el carnaval (...) para mí modelar es sacar el alma, sacar el corazón para demostrar lo que uno pude hacer y puede demostrar lo que es nuestro departamento, lo que es nuestras raíces, lo que es nuestro mestizaje.

Las palabras del maestro Chicaiza - heredero directo del desaparecido maestro Alfonso Zambrano -, hacen eco de quien constituye para al arte carnavalesco modelo por excelencia y referencia obligada. El maestro Zambrano recuperó los motivos autóctonos y diseñó los primeros movimientos mecánicos. Su testimonio acentúa en el alma y el amor que poseen los artesanos por la tierra de origen:

Los artesanos somos amantes verdaderos de la tierra. Creo que el carnaval es la fiesta del amor por ella (...). No estaba bien cuando se pensaba en mostrar solamente cuadros de otras partes: Europa, Asia, África, mientras cerrábamos los ojos ante el medio en el que vivíamos. Uno no es de allá. Uno es de acá. Uno debe modelar siempre lo que esta palpando, oliendo, oyendo y viviendo: lo que está soñando y amando. El sentir de donde está viviendo (CORDERO, 2007: Proemio).

Se puede concluir que el modelado en barro es la más antigua y prestigiosa técnica de los maestros creadores de Carros Alegóricos; no obstante, además del reenvío mítico-religioso y del acento etnocultural que hacen los Maestros Zambrano y Chicaiza, hay una apropiación particular del arte como modo para acontecer la vida y tramarla a la tierra, al pueblo, al inconsciente. No es acaso eso ċlo que evoca la mano siniestra que se abre y cierra, mientras el curaca, taita o indígena visionario toca su flauta y bailan al son mujeres multicolores que, según la leyenda inca "vírgenes del sol", serán sacrificadas en homenaje a los dioses? El retorno de lo que estaba escondido y pulsando en el subconsciente colectivo, lo expone en su obra el artista del carnaval que, además, queda representado también en la mano y su goce; él mismo va a un lado dirigiendo la escena (Figura 1).

El Maestro Raúl Ordóñez, más joven que los anteriores, situándose desde la enunciación colectiva de taller, subraya:

hay un placer estético y también sensorial al trabajar con el barro, en esta forma es una caricia con la tierra en donde todos estos personajes que están surgiendo del barro forman parte de nuestro interior, de nuestro propio Yo, pero 
que también en el fondo le pertenecen como al mundo, como a la comunidad, al pueblo.

Lo dicho, el artista popular en un médium, chivo expiatorio de la multitud, sacerdote secular o chamán que carga con la culpa y que busca redención colectiva con su obra. Su yo es, en realidad, nosotros.

\section{LAS FUERZAS ENCONTRADAS}

A esta altura ya se pueden leer las fuerzas encontradas, por un lado, la celebración pagana, subversiva de toda norma y de toda ley, la exposición excesiva del cuerpo y los sentidos, algo muy cercano a lo que Mijail Bajtín denominó como "realismo grotesсо": degradación de lo sublime, materialización del mundo por la risa. Y por otro, la sublimación del acto creador del artista que es capaz de situarse por encima del pueblo, representándolo. Mucho de tragicomedia barroca hay en todo esto, de topografía, sin duda: "Lo "alto" es el cielo; lo "bajo" es la tierra; la tierra es el principio de absorción (la tumba y el vientre), y a la vez de nacimiento y resurrección (el seno materno)" (BAJTíN, 1974, p. 25). El cuerpo, entonces, en su relación cósmica tendría igual equivalencia: la cabeza representa lo alto y los órganos genitales, el vientre y el trasero, lo bajo. De suerte que el carnaval rebaja, acerca a la tierra, degrada predisponiendo la comunicación con el cuerpo y con una parte en especial, la inferior (vientre y órganos genitales), y en consecuencia con los actos como el coito, el embarazo, el alumbramiento, la comida y la satisfacción de las necesidades primarias.

¿Qué otra cosa puede significar moldear con el barro que no sea adorar la tierra, descubrir sus secretos? Pero, si la tierra como vientre cósmico representa la absorción y la resurrección, al manipular el barro con las manos y luego darle forma, hay simbolización temporal del mundo que, por el acto creativo, el artista ordena y entrega una obra alegórica al pueblo, es decir, una obra-espejo, una fantasmagoría efímera.

El Maestro Diego Caicedo, joven trabajador del carnaval pero con larga experiencia, vive una transición en la apropiación y empleo de los materiales. Es capaz de visualizar una innovación al interior mismo de lo tradicional, sin embargo cuestiona la utilización de materiales nuevos; su relato permite leer esa resistencia:

Me veo en la necesidad de empezar a trabajar con mis hermanos la guadua o el juco... atendiendo de pronto un consejo del Maestro Alfonso Zambrano, que decía que los temas de aquella época eran muy regionales y que las temáticas se las conseguía en los mercados, en los pueblos; mi hermano Gilberto lo que encontró en el mercado no fue de pronto el tema, sino el estilo de trabajo, o sea la técnica, porque mira cómo el juco ya entrelazado empieza a formarse una canasta y esa canasta resiste tantas cosas, resiste el mercado completo (...) Empezamos a crear un estilo de formas, un estilo ya de estructuras y se trabajaba el engrudo, entonces se empieza a tomar estos elementos sin meterme tanto a lo sintético, aquí es muy escaso, muy poco lo que se mira de los materiales nuevos, siempre se ha trabajado con el tradicional, que es la harina, inclusive más que la misma cola y el yeso, porque es lo que más da forma. 


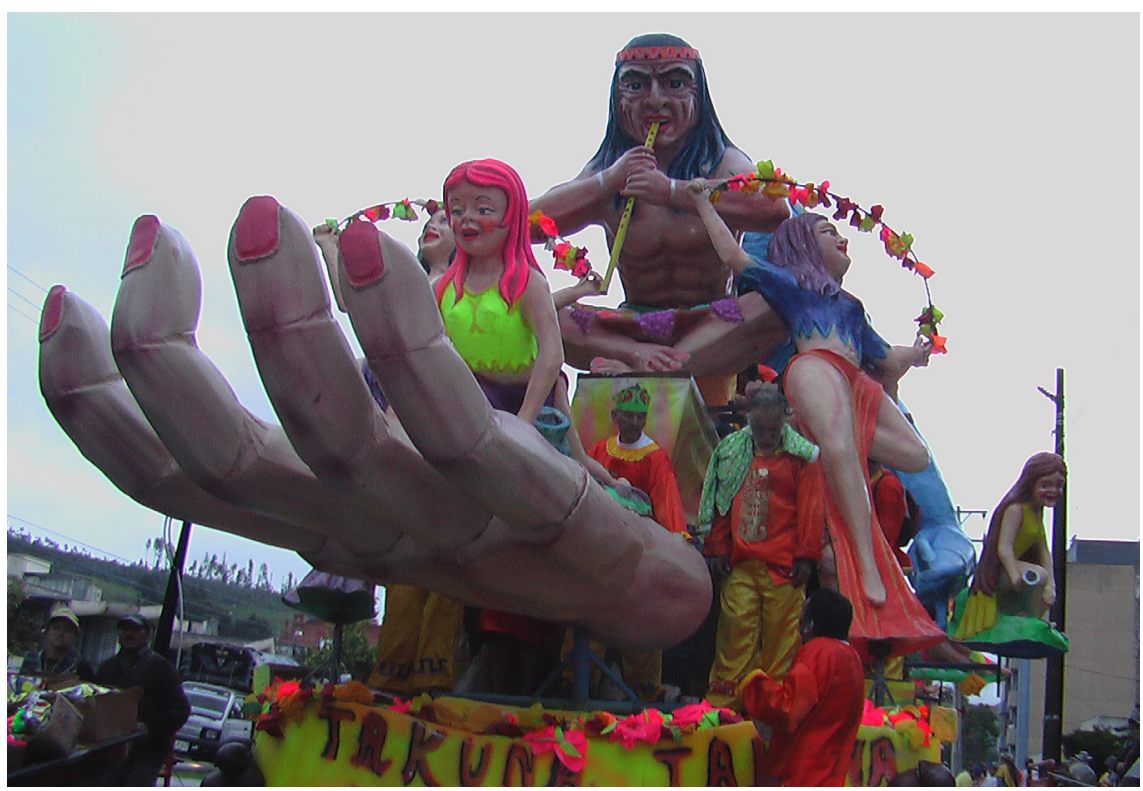

Figura 1: Virgenes del Sol, maestro José Ignacio Chicaiza Fotografía de Julio César Goyes-Narváez

\section{TRADICIÓN E INNOVACIÓN}

Acaso esta ambigüedad esencial, este oxímoron de mantener lo viejo y desear lo nuevo ¿̇es la experiencia que esperan las gentes que viven el carnaval el 6 de enero? Los criterios y modos de pensar de otros artistas del carnaval arrojan contrastes que pueden contestar a esa pregunta. Si bien todos los maestros referencian el barro por su tradición o por el valor que tiene para esculpir, muchos optan por trabajar con técnicas producidas por la industria, tales como el icopor y la fibra de vidrio. Hay muchos elementos de la modernidad que se traman con la tradición, pues el carnaval es también un territorio cultural para innovar sin perder la mirada ancestral. Para Roberto Otero, uno de los maestros carroceros más importantes, el legado de la tradición siempre va a estar allí, lo que le da identidad es la concepción que se tiene del trabajo, de su estilo, por ello considera que su familia ha comenzado a formar una escuela. Para él, pese a que en la región hay virtuosismo en el modelado en barro, éste al recubrirlo hasta con ocho capas de papel pierde la nitidez del modelado; el icopor, en cambio, no necesita sino dos capas y así aligera el peso. Esta es la razón para "dar a conocer este nuevo material, una nueva manera de trabajarlo", pero advierte que

lógicamente, al recurrir a elementos nuevos, la estructura cambia en cuanto a los elementos de la conformación. Por ejemplo, si antes se necesitaba de estructuras en hierro, estructuras en madera bastante voluminosas, de bastante consideración, ahora son muy ligeras;

no obstante, la factura es de alta calidad. 
De la misma forma, para Julio Jaramillo, mecánico y latonero de oficio, maestro experimentado e innovador en el empleo de materiales y en el diseño de movimiento de las figuras, los nuevos materiales perfeccionan el acabado y, además, solucionan problemas de resistencia.

La fibra de vidrio - dice - es un elemento que comenzamos a integrarlo a las figuras del carnaval de Pasto, debido a que, en época de carnaval, llueve y las figuras solamente en papel, yo miraba que a los compañeros se les doblaban, se quebraban, entonces miré que la fibra de vidrio nos da la posibilidad de aguantar el agua, nos da la posibilidad de no colocar hierro, sino con la misma fibra hacer estructuras.

Como el Maestro Otero, Jaramillo se aleja del contacto con el barro, del homenaje a la tierra en el sentido táctil y encuentra como mediación de un material innovador, otra ofrenda, esta vez a la acción práctica y eficaz de la tecnología moderna. Sin embargo, este gesto es irónico o mejor, alegórico, puesto que la cosa perderá su significado primario y ganará otros. La industria trata el material como útil para la vida y para el consumo diario, en cambio en el carnaval éste mismo elemento se pone al servicio del arte popular, de la contemplación y del gusto; lo que allá es perdurable, acá es efímero; no obstante, hay una leve diferencia con la técnica de modelado en barro, cuya figuras sufren deterioro casi inmediato, si bien la fibra de vidrio las vuelve resistentes, lo efímero de esas obras comienza a perder esencia. El sentido demiúrgico del acto creador pasa a ser diseño y cálculo, quizá por ello, esta técnica involucra temas prácticos o, como dice uno de ellos, "nos gusta trabajar más con lo de la vida real".

Acaso esta ambigüedad esencial, este oxímoron que mantiene lo viejo al tiempo que busca lo nuevo, este desear ver algo distinto sabiendo que envuelve lo mismo ¿̇es lo que esperan las gentes que viven el carnaval el seis de enero? Contestemos con el maestro Sigifredo Narváez, el más viejo de todos los artistas carroceros cuando se le pregunta por la relación entre la forma cómo realiza su carro alegórico y el motivo que porta:

El pinocho es lo tradicional, que un señor quería tener un hijo y no lo logró hasta que como era carpintero lo tallaba, yo así tuve mis hijos y los formé en barro y les echaba papel para ver si así seguían la tradición del papá, tanto bregué, tanto hice y lo logré.

En los relatos del tacto se lee un intento "abismal" por conservar la tradición como una forma de no olvidar el pasado, pero al mismo tiempo se cifra el ansia de asumir la innovación, triunfo y angustia, sin duda. Los artistas populares se someten al acto lúdico y bajo de tocar (manipular) la tierra, es verdad, mas es desde ese magma amorfo y dionisiaco que ordenan el mundo en alegorías; su lucha, entonces, es no dejarse vencer por el caos del barro y de los materiales industriales. Acto ético y estético que modela, refigura y esculpe, hasta lograr crear una obra monumental que muere y renace cada año, dimensión simbólica de su propio mundo interior. El acto ritual de reducir a cenizas su obra después del carnaval, remarca sin lugar a dudas, lo efímero de la vida. Es esto lo que comparten al pueblo en un gesto de dignidad y fortaleza. Ante esto sólo los aplausos y los no menos conmovedores silencios. 


\section{OBRAS DEL IMAGINAR}

En su estudio sobre los orígenes del drama barroco alemán, Walter Benjamin, observó cómo el clasicismo y el romanticismo tuvieron una postura crítica frente a la alegoría, considerándola inferior al símbolo, "una técnica gratuita de producción de imágenes" (BENJAMIN, 1990, p. 155), una especie de arrojemos al aire objetos a ver qué forman cuando caigan al suelo. Fondo oscuro y transitorio fue lo alegórico sobre lo que brillaba la luz de lo simbólico, de lo inmutable. Lo que yace en el fondo es una concepción del tiempo. Si el símbolo se presenta como igual a sí mismo, como unitario en la medida que compacta lo sensible con lo suprasensible, la omnipotencia del presente eterno, la alegoría acompaña el suceder del tiempo, se percata de la transitoriedad, de la brevedad, de lo efímero, por eso hurga en lo que queda del pasado, en las ruinas y lo decadente. Si en lo simbólico hay redención, en la alegoría hay destrucción, culpa, no es posible salvación alguna, a no ser como redención pasajera, por ejemplo en el carnaval y el arte popular que crea Carros Alegóricos, de allí su repetición año tras año, experiencia que Susan Buck-Morss releyendo a Benjamin vía Baudelaire, llama "el shock de lo nuevo y su incesante repetición" (BUCK-MORSS, 1995, p. 217).

Para Walter Benjamin, la alegoría nunca fue menos que el símbolo. La tradición occidental vía Descartes-Platón siempre tuvo reservas hacia la imaginación, una suprema desconfianza a la imagen; es fácil comprender por qué la precaria atención a la cultura popular y al carnaval, cuya acción creadora se da a través de imágenes. Este desprestigio de la imagen construyó prejuicios frente a su práctica y su uso: o son portadoras de realidad o son mentira. Lo cierto es que la experiencia audiovisual, a través de la fotografía y luego del cine, cuando volvió a representar la ciudad y con ella la cultura popular en su compleja relación con lo masivo, cambió la concepción hegemónica en el discurso de la crítica que reducía la imagen a mera instrumentalidad, poniendo la atención en los nuevos regímenes del percibir y del expresar. De allí que la experiencia audiovisual del Carnaval y con ella la creación de Carros Alegóricos, es un acontecimiento artístico, entre otras razones, porque lo estético cobija no sólo al arte clásico sino a todas las formas de lo sensible.

Los maestros del carnaval, al tiempo que construyen artefactos con las manos, relatan lo que hacen e imaginan sus obras: un saber-hacer y un hacer-saber, pero además, un saber estar en el mundo. Hablando desde espacios insondables, oníricos, subjetivos e inconscientes, construyen un relato barroco - recargado de materiales, cuerpos imaginales y significados -, una dimensión alegórica que transporta el sentido como dialogía o plurivocidad, pues son sujetos que sufren el desgarro que resulta de enfrentar lo local a lo global, en una sociedad que produce para el mercado. Sus preocupaciones temáticas tan míticas y humanas, tan sociales como científicas, soportan las estructuras invisibles de sus imaginarios alegóricos tradicionales como "otro discurso" que es preciso leer, para encontrar de forma moderna el "discurso del Otro", el lenguaje del inconsciente, la escritura del deseo colectivo. Esto significa que los Carros Alegóricos se constituyen 


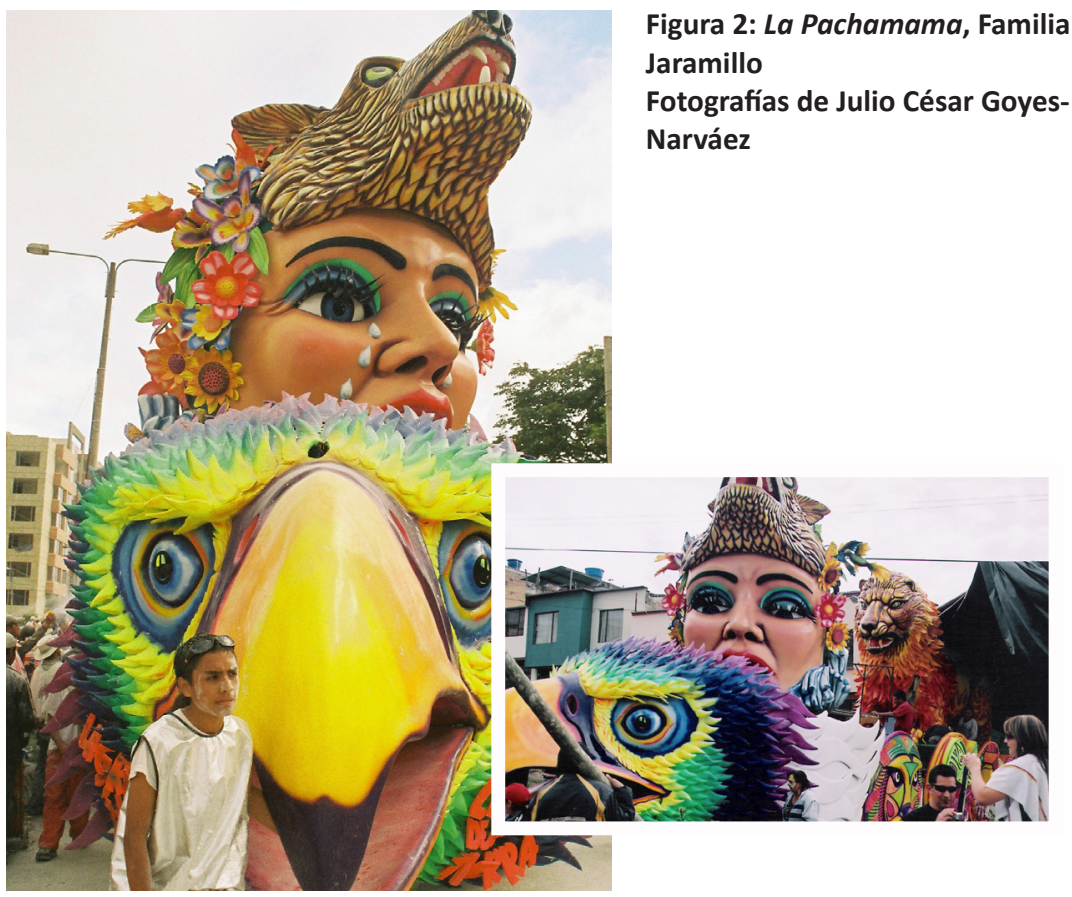

mediante la práctica de la lectura y la contemplación como textos e imágenes, es decir como escritura,

pues la lectura alegórica - no su exégesis erudita y ordenada tipológicamente o regulada de modo lógico-sistemático - permite que las imágenes o los textos se vuelvan escritura, una escritura de la que el sujeto se haga responsable (WEIGEL, 1999, p. 178).

\section{LA PACHAMAMA}

Andrés Jaramillo, hijo del Maestro Julio Jaramillo, quien diseñó la carroza La pachamama (Figura 2) y que resultó ganadora el pasado 6 de enero (2009), relata su motivo, concentrándose en el mensaje:

Una de las figuras principales es esta cara, una cara de una mujer, representa la tierra. El tema de este año es sobre el calentamiento global; es un tema actual y nosotros lo quisimos acoplar al carnaval, buscamos la mejor alternativa y miramos que debíamos hacer una cara. ¿Por qué una mujer?, porque la tierra en sí es la mamá de todos, la que nos da de comer y, como siempre, la mujer es la que ha dado vida, por eso la hicimos como todo el mundo la conoce: la famosa pachamama.

La famosa "Pachamama" es demasiada abstracta para que todo el mundo la conozca y sepa de qué se trata, aunque la cara zoomorfa de la mujer algo de extrañeza causa en los espectadores. No obstante la estética naturalista, es otra la atracción y la experiencia. Es cierto que su tema evoca el mito quechua y aimara de "la Pachamama", dei- 
dad cotidiana que actúa por presencia y con la cual se dialoga permanentemente, ya sea para pedir alimento o disculparse por las faltas cometidas en contra de la tierra y todo lo que ella provee. Más protectora y proveedora que creadora, esta divinidad posee también su faz negativa; si no se la provee de ofrendas, provoca enfermedades y castiga con catástrofes. El Carro Alegórico de la Familia Jaramillo intenta concientizar sobre el abuso del hombre con las riquezas que proporciona la tierra, por ello la diosa llora transmutada ya en tigre (arriba), ya en cóndor (abajo), y en su lomo-loma del león enorme que va en la parte posterior, va montado un indígena de grandes proporciones; curiosa inversión topográfica para estos animales totémicos de la región, casi extinguidos: el uno guardián extraordinario de las alturas andinas, figura emblemática del escudo nacional; el otro, guardián espiritual de la selva en las frondas de la conversión chamánica, último escalón en la toma sagrada de yagé; más sólo se habla de la "cara de una mujer" que alegoriza la tierra, mamá de la humanidad que va delante, nada se dice del león que va detrás, como configurando un triángulo, en cuyo centro está la cara de una mujer que llora. Quizás la ubicación de las figuras no es sino otra solución a la estructura de la carroza, pero el texto no escapa a una lectura de los emblemas ubicados en torno a la cara de la mujer: Ley, contemplación y sigilo. El dispositivo que motiva la idea junto a los materiales que agencian lo estético, propician más que una toma de conciencia sobre el calentamiento global, el mito local de La Pachamama, sin embargo éste queda oculto en la admiración a la técnica de fibra de vidrio y a los movimientos eléctricos, a su conmovedora belleza, a su equilibrado color y acabado luminoso.

\section{PRIMERO FUE EL SUEÑO Y LUEGO LA INVESTIGACIÓN}

Uno de los maestros más jóvenes y destacados artistas del carnaval, Hugo Moncayo, continúa trabajando con la técnica tradicional del modelado en barro; cuenta que su motivo, El guardián del fuego (Figura 3), se debió a un sueño

donde se miraba un pájaro con una cola multicolor que estaba como volando con un trasfondo del volcán, como con la vista que tenemos desde esta casa, con un atardecer como un ocaso y había dos pájaros que los seguían; en el sueño yo quería mirar la figura de enfrente que era como la que me llamaba más la atención por sus colores, pero era como si se me corría la cámara y me enfocaba sólo los dos pájaros de atrás que eran como una especie de halcones o como unos gavilanes, como los que se saben venir a comer las tórtolas aquí al árbol de pino.

Los imaginarios que involucra en su Carro Alegórico tienen que ver con diferentes sucesos, ente ellos, con la activación del volcán Galeras desde hace varios años, guardián de la ciudad de Pasto. Resignados a una explosión de grandes proporciones, los habitantes conviven con su rugido de pantera o puma ancestral. Más allá del temor, la gente, en su mayoría campesinos, consideran al Galeras como su protector y guía espiritual, y pese a que las unidades de socorro previenen con la evacuación, los habitantes de la zona aledaña al volcán no se mueven.

Tanto la cola del pájaro multicolor (que se aproxima a la imagen del pájaro de fuego de los cuentos rusos: maravilla y maldición) como el puma ancestral, reenvía al 


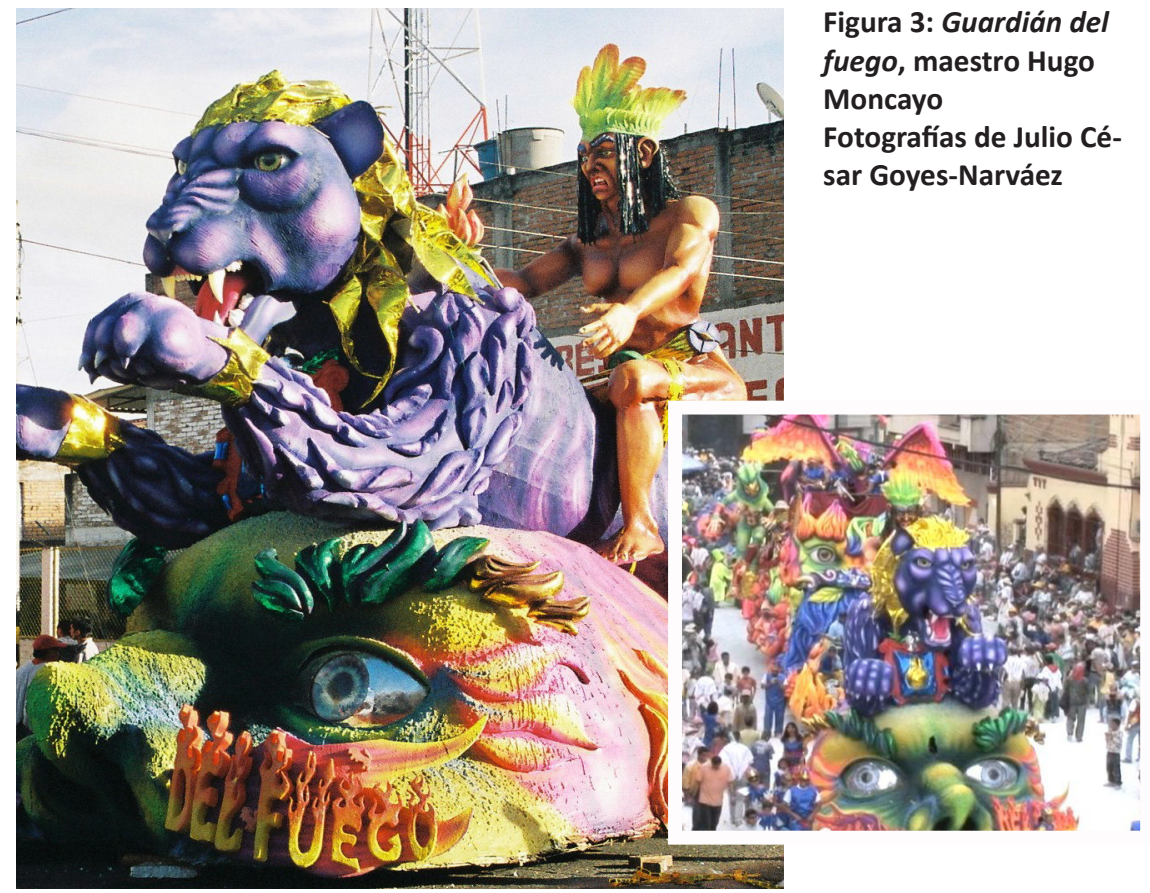

acto chamánico y al mito latinoamericano de la creación: muerte y resurrección. Como se puede leer en el testimonio, el Maestro Moncayo no logra en el sueño ver al pájaro multicolor, "era como si se me corría la cámara", dice. En cambio focaliza halcones y gavilanes, pájaros locales que sobrevuelan el volcán Galeras y la casa donde el artista habita, a las afueras de Pasto, arriba de una loma asentada sobre una cantera de barro. De hecho el pájaro multicolor o de fuego en la mitología, hizo parte de la composición (detrás de la figura central) irradiando todo su color y movimiento en los bastidores de la carroza, imágenes de rostros blancos y negros que irradian Ilamas multicolores. El pájaro de fuego alegoriza la belleza y la vanidad, en el pavo real, por ejemplo, o es el quinde (colibrí) civilizatorio que dona el fuego a los Jíbaros - comunidad indígena del Ecuador. Tal como poliniza las flores, el quinde mensajero del fuego, conecta los inframundos con los supramundos en las frondas de lo imaginario. El mito universal de Prometeo en su versión criolla está convocado: quien cuida el fuego de los dioses un día lo roba para entregarlo a los que no lo tienen, los humanos, aunque dicho sea de paso, si ese fuego lo entrega el volcán, otro relato sería. Los pájaros que acompañan el motivo central y que son locales, guardan debajo del pico un rostro de mujer.

Vale la pena señalar que tanto La pachamama (Maestro Jaramillo), Vírgenes del sol (Maestro Chicaiza) y el Guardián del fuego (Maestro Moncayo) son carros alegóricos que se identifican en el empleo de motivos similares, no así en el punto de vista, la técnica y la composición. Comparten la madre tierra, el elemento zoomorfo y el indígena que, trepado en los lomos o ubicado en la parte más alta, oficia y dirige la escena, parece con- 
Figura 4. Sorpresa Andina, maestros Hnos.

Caicedo

Fotografía de Julio César Goyes Narváez

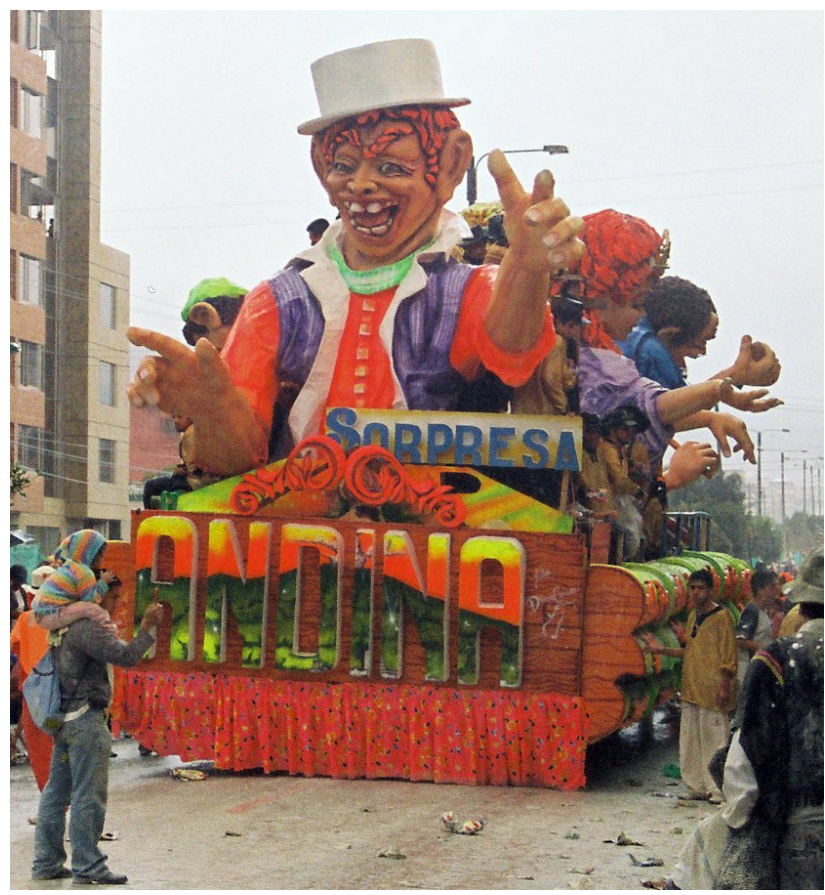

trolar o desbordar la furia de los animales-humanos. Desde luego que en el Guardián del fuego - y en Vírgenes del sol por su mano inquietante -, el sujeto experimenta una cercanía escalofriante entre el ser y el significar de la imagen, sufre una experiencia que no está en La pachamama por bien acabada y preciosa que parezca. En el Guardián del fuego la personificación del volcán Galeras - uno de los más activos del mundo- se da a través de una máscara con ojos enormes y de la traslación de su fuerza y rugido a la pantera o puma negro, animal que encarna los saberes del chamán, curandero y guía, que en su versión de hechicero posee la capacidad de transformarse en felino y andar por la tierra cuidando o devorando, según sea el contexto del mito en Latinoamérica. No hay que olvidar que el chamán es un intermediario entre los hombres y los dioses o espíritus, así como el artista del carnaval media entre la cultura y el pueblo.

\section{SORPRESA ANDINA $Y$ EL ARLEQUÍN}

Entre los carros alegóricos y su significado hay una distancia como huella de recuerdos que en el procedimiento de construcción alegórico son constantemente ocultados y recubiertos como capas de papel en el barro, a veces tienden a esquematizarse como un saber fijado que los maestros del carnaval reverencian como emblema: imagen y signo, al tiempo. Este es el caso de dos artistas de larga trayectoria en el carnaval de Negros y Blancos: el maestro Diego Caicedo, que con su tradición de la caricatura - hipérbole, ternura y picardía -, relata su imaginario como Sorpresa Andina (Figura 4), composición con la cual desea rendir un homenaje a la ciudad y al mismo carnaval: 


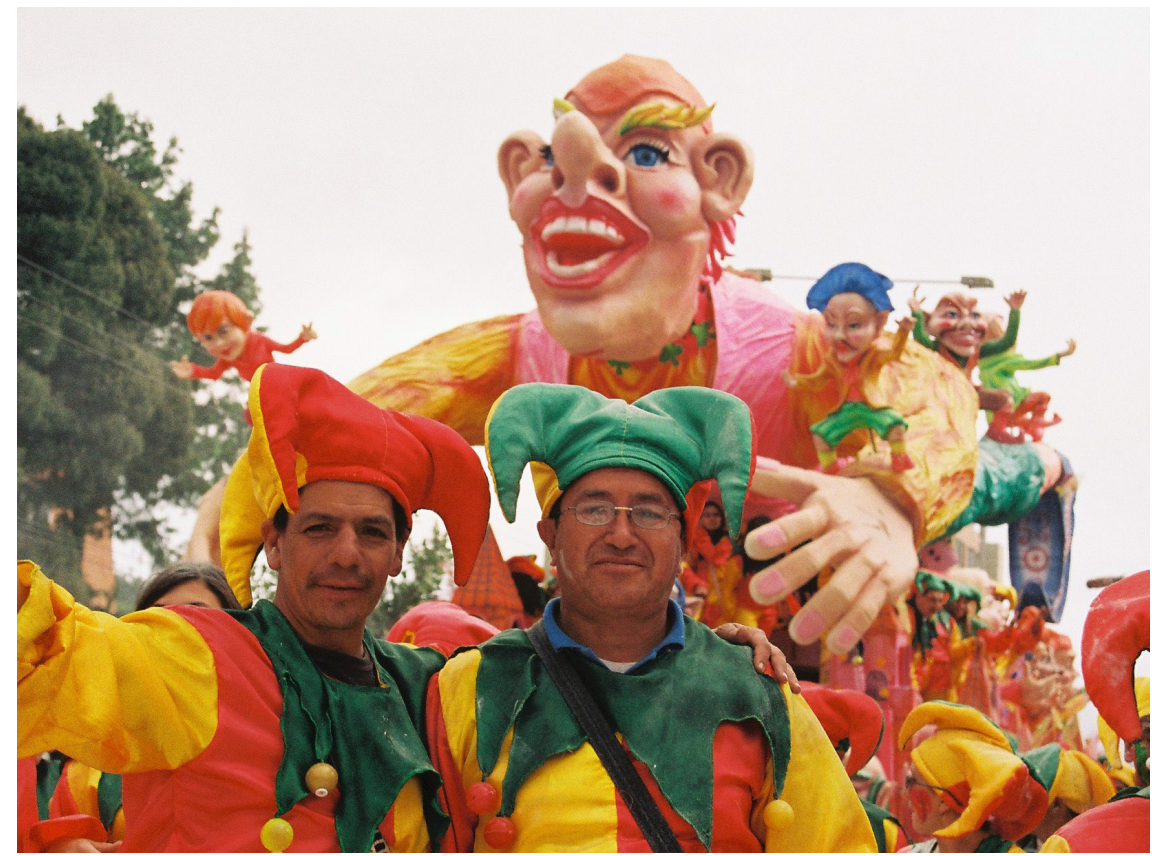

Figura 5: El Arlequín, maestros Hnos. Erazo Fotografía de Julio César Goyes-Narváez

Adelante pues tiene que ir Pericles Carnaval, que es un personaje que así se lo repita todos los años, éste es un icono que ojalá nunca falte en cada carroza, así sea en las camisetas, en los bastidores, en alguna parte, porque éste se lo tiene que adoptar como uno de los símbolos de nuestro carnaval; entonces, lo estoy poniendo en una parte gigantesca adelante y él es el que abre unas letras de dos metros cada una de la palabra Andina, él abre su mano y mueve las letras. Cuando las letras abren, en la parte de adentro, se muestran imágenes como otro símbolo del carnaval que es Alfonso Zambrano, él va pintando con

9 Campesina de la región andina nariñense, de carácter recio, voluntariosa $e$ independiente. aerografía en la parte interna. También está Pedro Bombo, quien acompañaba las festividades de nuestro carnaval; acompañaba la fiesta de los pueblos, y en el centro donde se abren las letras aparece la Virgen de las Mercedes como dedicándosela a un pueblo religioso. En la parte de atrás aparece una Guaneña ${ }^{9}$, de un tamaño de tres metros que se levanta y en su mano lleva una iglesia y en la mano izquierda ésta lleva un antifaz como símbolo de nuestra idiosincrasia; devoción y fiesta es más o menos lo que quiero presentar.

Las figuras emblemáticas de la fiesta del sur, la insistencia en la tradición, y pese a la risa que habita en sus figuras está lo serio de sus símbolos: devoción y fiesta. Esta ambigüedad entre lo transitorio y lo perenne cobija la experiencia de abandono y reconciliación, de culpa y redención. Por eso la conciencia de que es preciso repetir, volver a hacer, lo nuevo finalmente es lo viejo, toda innovación no es más que una fantasmagoría, una 
eterna repetición de lo mismo, como lo filosofó Nietzsche y como poetizó Baudelaire, a partir del mito del eterno retorno. ${ }^{10}$

De igual forma, en el imaginario de la carroza del maestro Felipe Erazo, Arlequín, un cuento sin fin (Figura 5), la alegoría se carga de sentido al burlar la seriedad efímera de la vida. Al volver sobre la fantasía y la risa eufemiza la conciencia de la muerte construyendo la alegoría de un estado propiamente carnavalesco, corporal, vulgar y materialista; al tiempo construye un relato de fantasía, un cuento de hadas degradado como simple escape y alegría, justo en el acontecer de un mundo que ya no cree en ellas:

En la época de los reyes a él lo invitaban a los castillos para que divirtiera a los reyes y al mismo tiempo se burlaba de ello, y el arlequín en sí es una persona, no como es, es un elemento que es base fundamental del teatro, sea como sea, por eso se le llama arlequín un cuento sin fin, porque el arlequín nunca va a morir (...) estamos trabajando con el cuento de la fantasía, del castillo, de los duendes, de las hadas, entonces ya en conjunto la carroza se la podrá apreciar.

\section{LA CAJA DE PANDORA}

El mundo imaginario del carnaval permite la oportunidad de cambiar los roles. La máscara y el maquillaje dejan salir ese otro interior que se agazapa en el inconsciente. Reactiva la identidad comunitaria, fortalece y replica burlonamente el sistema social, se constituye como una válvula de escape, una liberación episódica de tensiones, mediante la cual se logra garantizar la estabilidad social. Esta expresión popular unida al teatro callejero, a la danza folclórica, a la escultura vanguardista, a la poesía y narración oral, constituye una alternativa estético-cultural frente a los espectáculos estériles. Sin embargo, algunos sectores sociales siguen mirando de manera despectiva a estas manifestaciones populares, sin valorar su ética, su crítica y elaborada estética popular, que va más allá de la cultura de masas.

El lenguaje no convencional del carnaval inserta los juegos de máscaras, los movimientos y apetencias del cuerpo, los gestos libres, las escenas improvisadas y múltiples, las escenografías sugerentes, las planimetrías sorpresivas. El carnaval expresa las excentricidades psicosociales; la fusión en oxímoron entre lo sagrado y lo profano, lo sublime y lo grotesco, la sabiduría y la "tontería", profana y parodia comportamientos, formas de pensar, de actuar y de sentir, en el orden sexual, religioso, social e íntimo del ser humano. Un espacio antes que "real" y "ceremonioso", poetizado e imaginado, vívido y proyectado como gesto hiperbólico y surreal, como apunta el Maestro Raúl Ordóñez al señalar que tal vez "el carnaval es nuestra vanguardia" porque "es la afirmación de que otros mundos son posibles". Su compromiso ético cuestiona los motivos realistas del costumbrismo, por eso apela al mito universal para consolidar un mensaje de crítica social que involucra lo nacional en lo local.

GOYES-NARVÁEZ, Julio César. Los carros alegóricos del carnaval de negros y blancos 


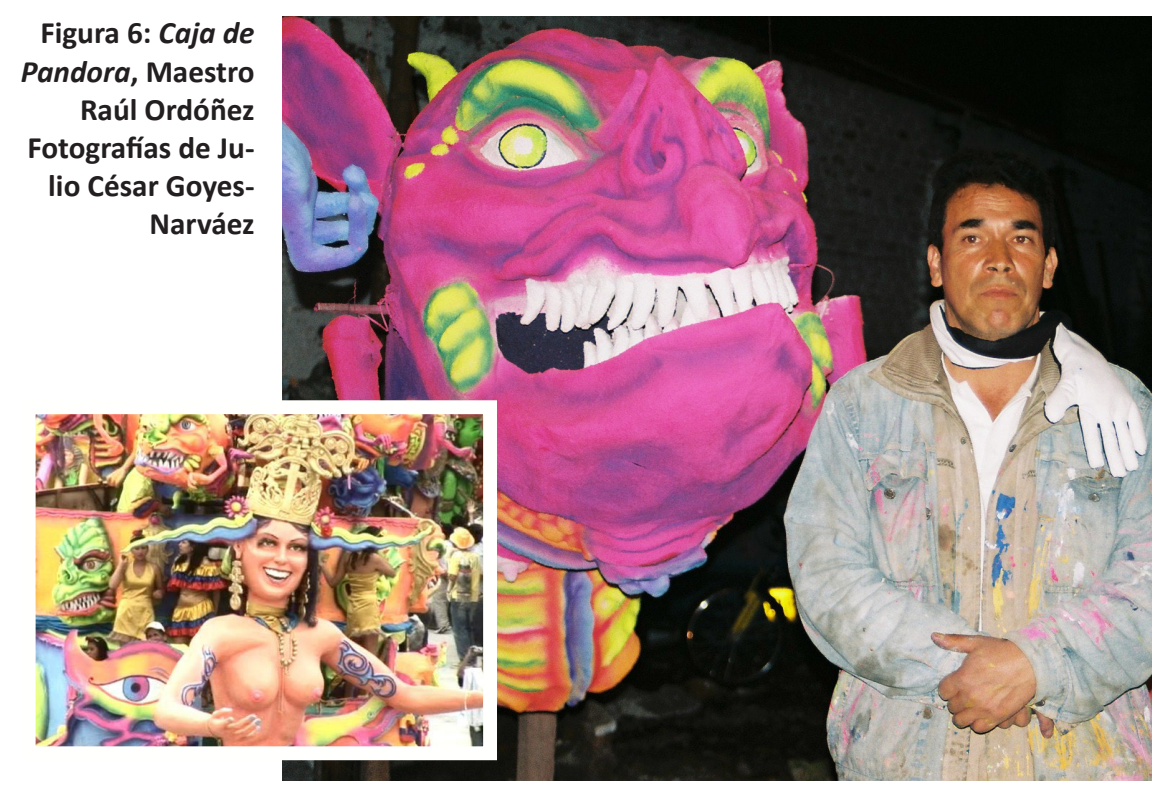

Con la Caja de Pandora (Figura 6) - relata el Maestro Ordóñez -

estamos representando una parte pequeñita de la realidad, pero mirando desde el punto de vista del arte, pensamos que esta Caja de Pandora es todo lo malo que se ha destapado aquí en Colombia, y nosotros pensamos que todo en este mundo tan terrible que ha pasado en Colombia, esa Caja de Pandora que se ha abierto, debe cambiar porque aún conservamos la esperanza, que en últimas es lo último que se pierde, como dice ese viejo refrán, ese viejo adagio.

Las imágenes que transporta este carro alegórico son deformes y estrambóticas, acabadas en texturas rugosas y colores psicodélicos que recuerdan las imágenes hippies. Dos calaveras cuelgan a lado y lado de los bastidores, en el centro se eleva la figura de una mujer desnuda que muestra lascivamente sus pechos y deja ver sus dientes con manifestación de su goce. Ya lo decía Walter Benjamin, lo hemos citado en otro lado,

mientras que en el símbolo, con la transfiguración de la decadencia, el rostro transformado de la naturaleza se revela fugazmente a la luz de la redención, en la alegoría la facies hipocrática de la historia se ofrece a los ojos del observador como un pasaje primordial petrificado. Todo lo que la historia tiene de intempestivo, de doloroso, de fallido, se plasma en un rostro o, mejor dicho: una calavera (BENJAMIN, 1990, p. 159).

Calavera que se agazapa a los lados, pero que está en la carcajada de la mujer y en el goce de su cuerpo.

\section{EVOLUCIÓN Y CREACIÓN, ESA ES LA CUESTIÓN}

El último maestro convocado es Carlos Insuasty, joven pero experimentado artista popular. Se ha dejado al final por la sugerente alegoría que porta su carroza: la 
Figura 7: El carnaval: una obra artística de la creación, Maestro Insuasty Fotografías de Julio César Goyes Narváez
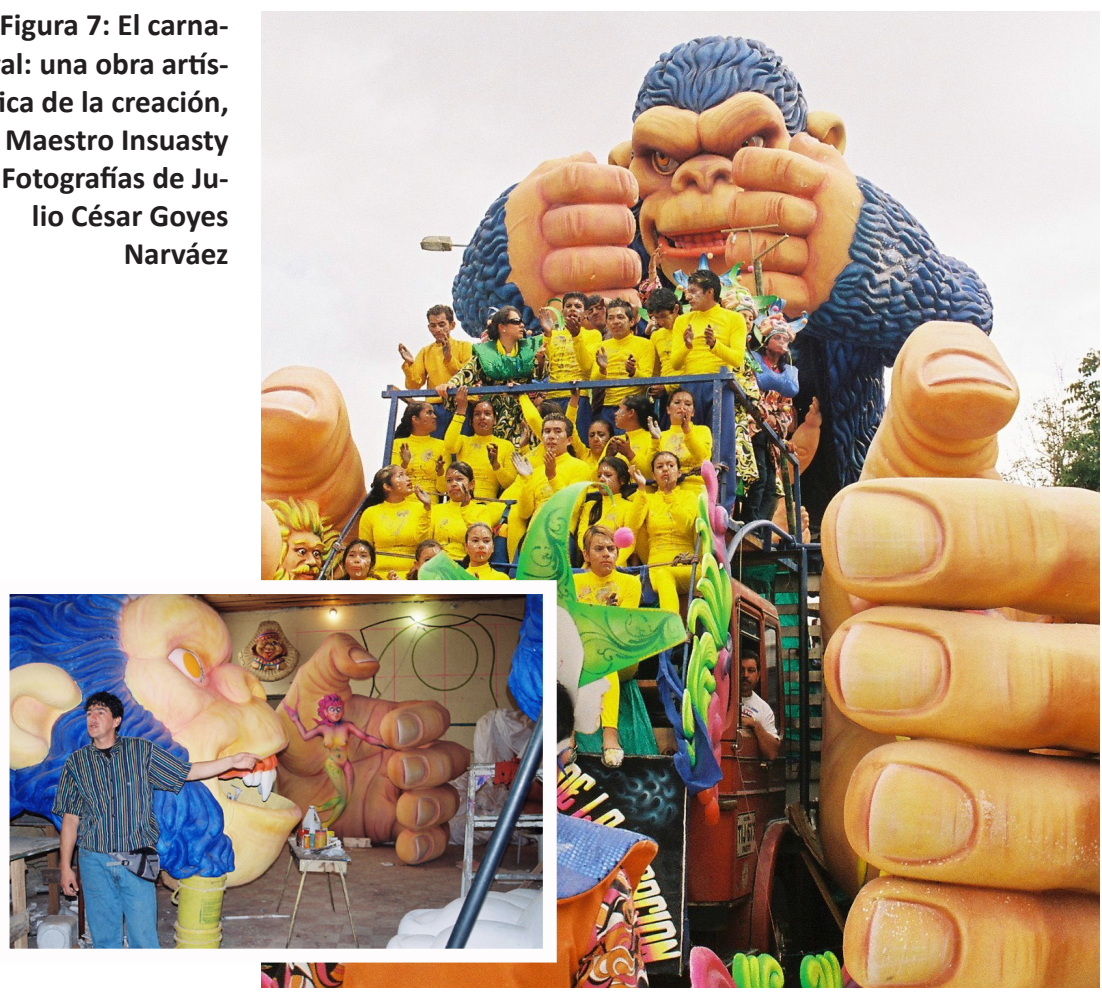

Fixe

creación y la evolución. Apoyado en la historia y en los materiales industriales, el Maestro Insuasty levanta la figura de un mono más de 32 metros (Figura 7), inaugurando sin duda la etapa monumental del carnaval en Nariño. Pero lo que inquieta de esta carroza no es tanto el tamaño y su técnica, que es de gran factura y una de las más experimentales, sino el motivo que la genera y la composición que expresa ese motivo. Un mono enorme con los brazos abiertos y las manos ligeramente empuñadas. Acunado en su pecho sobresale un niño con los brazos levantados en signo de alegría, al frente del carro y en los dos costados dos manos gigantescas riman con las del mono y las del niño, pero en proporción desigual: en las palmas de las manos están tallados los cuerpos desnudos de un hombre (derecha) y una mujer (izquierda). Las manos se cierran y abren permitiendo ver en cada movimiento a 22 jugadores que van sentados celebrando mientras la carroza avanza. La composición no puede ser más cinematográfica, un ritmo planificado proporciona cierta armonía: al tiempo que se abren las manos, el mono se yergue.

Algo, sin embargo, llama la atención: por un lado, el título del carro alegórico El carnaval una obra artística de la creación; por otro, la evolución alegorizada que se lee a partir de las manos y brazos como prolongación de las del mono simiesco y de las del niño, en segundo plano casi imperceptible. El envío inmediato es a la teoría de la evolución, conmemorando quizá con ello los 200 años del nacimiento del naturalista inglés Charles Darwin; pero hay más, los cuerpos desnudos que se desprenden de las palmas 
de las manos enormes representan a Adán (derecha) y a Eva (izquierda), simbolizando la creación divina. El significado parece empañarse en este punto: evolución y creación, los dos al tiempo. El título dice que el carnaval es obra artística de la creación y ésta se representa en las manos que portan a Adán y Eva, menos perceptibles; sin embargo, el mono enorme que se levanta por encima de esas manos alegoriza la evolución. De suerte que el carnaval de Negros y Blancos es un acto demiúrgico un tanto escondido, al tiempo que fruto de la evolución socio-histórica totalmente visible. No es descabellado leer en esta imagen una crítica al despliegue comunicativo e informativo que se hace en época de carnaval, privilegiando el espectáculo, pero nada, o muy poco, se dice de quienes lo crean y mantienen. El Maestro Insuasty construye su relato desde el mito y la ciencia, y desde su propia subjetividad creativa a la que rinde homenaje, según sus palabras:

Hay una creación, hay una evolución, científicamente quizá a través de los simios, a partir de los monos, católicamente, religiosamente y respetando esa parte, sencillamente estamos haciendo una alusión aquí, gráficamente de una manos que van a abrir en un determinado momento, son lógicamente mis manos porque las hice mirando mis manos, porque tienen las venas, todas las facciones que tienen; estas manos son mis manos, las manillas o la parte final de estas manos son unas manillas parecidas a una chaquira, chaquira que tenía yo en ese momento cuando comencé a hacerlas y que se asemejan a las chaquiras que se usan en el Putumayo, y digámoslo así, que son las manos del creador quien las quiera tomar, y las manos mías porque lógicamente yo soy el creador de esta obra junto con el equipo de trabajo.

Sin embargo, nada está resuelto y caben varias interrogantes: ¿el mono es como ese recién nacido que acuna en su vientre?, ¿es el mono el que habita dentro del hombre y clama por salir como el bebé de su vientre?, ¿el bebé es como el mono cuando está recién nacido?, ¿̇las manos gigantescas que van al frente son fruto de la evolución y por tanto prolongación de las manos y el cuerpo del mono?, ¿el bebé se convertirá en mono cuando crezca? y ¿̇i el mono representara al jugador del carnaval? Nada impide imaginar que en el juego carnavalesco sus participantes actúen como monos. Es posible una pregunta más: ¿̇los veintidós jugadores que van sentados en la parte frontal de la carroza, que son protegidos al tiempo que mostrados por las enormes y no menos siniestras manos - pues no se desprenden de cuerpo alguno -, no se ven diminutos y aplastados por la grandeza del mono? La teoría de la evolución está trastocada, sin duda, como en efecto lo está el mito de la creación divina, pues es un mono (¿el carnaval?) el que dirige la escena. Cabe todavía otra posibilidad: o bien la humanidad se animaliza o la humanidad, representada en el niño, apenas si se desprende de su fase simiesca. Estas preguntas no pueden ser resueltas con facilidad, qué sentido tendría en una cultura descreída, que ha cuestionado sus relatos y que ha extinguido sus mitos. El carro alegórico del Maestro Insuasty deja la inquietud de que tal vez todavía es posible y necesario, convivir con la mitología y la ciencia.

La alegoría de las manos cierra este texto, las manos del hombre en su evolución a partir del trabajo - la cita es a Friedrich Engels en "el papel del trabajo en la transformación de mono en hombre" -; las manos de Dios que hicieron de barro al primer hom- 
bre y con su soplo divino le imprimió vida; las manos de los artistas populares del carnaval que, lejos de aplicar una técnica gratuita de producción, manipulan elementos reales, imaginarios y simbólicos, con los que crean imágenes complejas, textos o macrotextos donde habitar, no sin sosiego, con el sentido.

\section{REFERENCIAS BIBLIOGRÁFICAS}

BAJTÍN, Mijail. La cultura popular en la edad media y renacimiento: el contexto de François Rebelais. Barcelona: Barral Editores, 1974.

BENAVIDES, Rivera. Estampas iluminadas de los carnavales de Pasto. Programa de Carnaval de 1974. Pasto, 1974.

BENJAMIN, Walter. El origen del drama barroco alemán. Madrid: Editorial Taurus, 1990.

BUCK-MORSS, Susan. Dialéctica de la mirada. Madrid: Editorial Visor, 1995.

CORDERO, Lydia Inés Muñoz. Memorias de espejos y de juegos: historia de la fiesta y de los juegos del carnaval andino de San Juan de Pasto. S. I.: Ediciones Edinar, 2007.

GONZÁLEZ-REQUENA, Jesús. Casa Blanca: la cifra de Edipo. Trama y Fondo, n. 7. Madrid, noviembre, 1999.

GOYES-NARVÁEZ, Julio César. El performance del carnaval. Ómnibus, n. 21, año IV, junio de 2008. http://www.omni-bus.com/n21/index.html. (Consulta 4 septiembre 2010).

PÉREZ, Marcos González. Carnestolendas y carnavales en Santa Fe y Bogotá. Bogotá: Intercultura, 2005.

TOBAR, Javier y GÓMEZ, Herinaldy. Perdón, violencia y disidencia. Popayán: Editorial Universidad del Cauca, 2004.

VOVELLE Michel. De la sociedad tradicional al estado moderno: la metamorfosis de la fiesta en Francia. (Ponencia en Encuentro Internacional sobre estudios de Fiesta. Bogotá. Noviembre 1997). In FIESTA y Nación en Colombia. Bogotá: Editorial Cooperativa Magisterio, 2004.

WEIGEL Sigrid. Cuerpo, imagen y espacio en Walter Benjamin: una relectura. Barcelona: Paidós, 1999.

XAVIER, Costa. De la orgía: Dioniso sin el bálsamo del arte y la fiesta de Grecia. Barcelona: Anthropos, 2007.

Sociability and the public sphere in the fallas of Valencia. PhD. Thesis, University of Warwick (UK), 1999.

ZARAMA Vásquez Germán. Sombras y luces del carnaval de Pasto. Bogotá: Edición de autor, 1999.

Julio César Goyes-Narváez es docente investigador del Instituto de Estudios en Comunicación y Cultura (leco) de la Universidad Nacional de Colombia y director de "Quinde audiovisuales", programa que desarrolla proyectos de investigación-creación en diversas regiones colombianas.

Artigo recebido em julho de 2010 e aceito para publicação em agosto 2010. 
